\title{
Human Milk \& Breast Feeding: Impacts on Child Health
}

\author{
Jharana Shah ${ }^{1 *}$, Gayatri Hamal' ${ }^{2}$ Seema Malla ${ }^{3}$ and AB Hamal ${ }^{4}$ \\ ${ }^{1}$ Lecturer \& Coordinator, Kantipur Academy of Health Sciences (KAHS), Purbanchal University, Nepal \\ ${ }^{2}$ Staff Nurse, Bir Hospital, NAMS, Nepal \\ ${ }^{3}$ Lecturer, Florence Nightingale Nursing College, Butwal, Nepal \\ 4Consultant Physician, Nepal police Hospital, Kathmandu, Nepal
}

Submission: November 20, 2019; Published: December 02, 2019

*Corresponding author: Jharana Shah, Lecturer \& Coordinator, Kantipur Academy of Health Sciences (KAHS), Purbanchal University, Nepal

\begin{abstract}
Breast feeding practices depend upon the maternal awareness, education, cultural practices, social taboos and working environment. Human milk evolves as colostrum to transitional milk and to mature milk providing nutrition and protection to the infant. Prelacteal feeding delays breastfeeding in many developing countries. Early initiation of breast feeding decreases the morbidity and mortality of neonates and strengthens the mother child interaction. Benefits of breast milk includes a wide range of coverage from health of infant to the adult life including that of mother. Encouraging mother, family members and ensuring the breastfeeding techniques and dissemination of current evidences about human milk at community level will help decreasing the morbidity and mortality. Human responsiveness is the fulcrum in fostering breastfeeding in developing and developed countries.
\end{abstract}

Keywords: Breast feeding; Benefits; Colostrum; Donor Human Milk; Milk Bank

\section{Introduction}

Breast feeding is a trunk of postnatal care in human life. Breast feeding practices depend upon the maternal awareness, education, cultural practices, social taboos and working environment. Associations between breastfeeding and infant outcome have been found in many studies though randomized controlled trial is not ethical to conduct with the replacement of breastfeeding. It has already been proved that human breast milk cannot be replaced by any formula feed or milk substitutes for neonates or infants unless there are contraindications. Innoceti Declaration [1] in 1990, advocated for exclusive breast feeding for at least 4- 6 months while World Health Organization (WHO) made it for at least 6 months and still to continue by the mothers [2]. World Breast feeding week (August 1-7) marks anniversary of the declaration. Breast feeding is equally important for mothers and children from low income countries to high income countries as it has impact on development of children as well as short term and long-term advantages to the mother [3]. This study highlights the importance of human milk and the breastfeeding practices that owe to the health and mother.

\section{Methods}

Original research articles, abstracts, reviews, guidelines, protocols and evidences related to the human breast milk and its benefits as well as breastfeeding practices were electronically searched, and freely accessible ones were included. The evidences from the recently published articles till November 2019 have been included.

\section{Discussion}

\section{Colostrum}

Human milk secreted from human breasts evolves as colostrum to transitional milk and to mature milk providing nutrition and protection to the infant. Mother's first milk, Colostrum, secreted in initial few days of postnatal period, is a unique bioactive substance, and has immunologic, nutritional, and developmental functions in the neonates [4]. Though colostrum produced is in small volume it is rich in leukocytes, protein, human milk Oligosaccharides (HMOs), and bioactive factors-IgA, LF, EGF, TGF- $\beta$, colony-stimulating growth factor, and antioxidants 
[5]. Oligosaccharides prevent attachment of common respiratory pathogens, such as Haemophilus influenzae and Streptococcus pneumoniae, to respiratory epithelium, and glycoproteins prevent binding of intestinal pathogens such as Vibrio cholerae, Escherichia coli, and rotavirus [6].

\section{Prelacteal feeding}

Prelacteal feeding (with a prevalence of 25\% -38\%) [7,8] which is a major unwanted practice, has negative impact on initiation of breastfeeding and is associated with risk of gastrointestinal infections [9] and finally a factor of early cessation of breast feeding by interfering with milk production and decreasing the mother and child skin to skin contact necessary for mother baby bonding $[10,11]$. A prelacteal feed is any food provided to a newborn before initiation of breast feeding. Prelacteal feeds may include boiled water, fresh butter [7], formula milk, cow/ buffalo milk or sugar/ glucose water12. According to V Khanal et al. [12], the prevalence of prelacteal feeding is $30.6 \%$ in Nepal. The misconception of prelacteal feed is that the mothers believe it to have laxative effect, clean meconium from the gut or has rehydration effect for newborns due to which the newborn are prone to contamination and diarrhea [13]. In many traditional societies, colostrum is considered harmful and discarded and prelacteal feeds can delay breastfeeding for several days $[14,15]$.

\section{Factors associated with prelacteal feeding are $[7,16]$ :}

a) Unaware mothers and advice from their parents

b) Home deliveries

c) Lack of breastfeeding counseling

d) Extended family type

e) Colostrum discarding

In Nepal the identified factors for prelacteal feeding are: Uneducated mothers, poor socioeconomic status, 1st birth order children, less frequent antenatal visits, mothers from terai region [17]. In contrast to these, a study done in Nairobi, the factors for prelacteal feeding were mothers with higher education and infants born through caesarean section [18].

\section{Composition of Human Breast milk}

Transitional milk follows colostrum and is secreted from 5 days to 2 weeks postpartum that finally matures at 4-6 weeks postpartum. Amounts of protein and Immunoglobulins decrease and lactose and fat and water-soluble vitamins with higher caloric increases to meet demands for infant growth while the quantities of bioactive factors decline over time. Amount of lyzosomes increase while mannan-binding lectin concentrations declines in transition from colostrum to mature milk. Then it remains constant after 6 weeks through the remainder of the lactation period $[19,20]$.

\section{Constituents:}

Some of the important constituents of human breast milk are:
Proteins: Human Breast milk consists two proteins: whey (70\%) and casein (30\%). Whey proteins contains majority of lactalbumin component to be easily digested and help in rapid gastric emptying. Whey proteins also include lactoferrin, lysozyme, and secretory immunoglobulin A (IgA) which are important for host defense [21-23]. Two amino acids viz. cysteine and taurine essential for synthesis of antioxidant glutathione and bile conjugation respectively [24,25].

Carbohydrates: Carbohydrates compromise about 40\% of calories in human breast milk. It consists of lactose and oligosaccharides.

Lipids: It constitute about $50 \%$ of the calorie for infants and may count to $4.7 \mathrm{~g} / \mathrm{dl}$ [26].

Minerals: The majority of macrominerals found in breast milk are calcium, phosphorus and magnesium including sodium and potassium. These are important for linear growth and bone mineralization and nerve functioning. The concentration of calcium is $250 \mathrm{mg} / \mathrm{L}$; phosphorus is $140 \mathrm{mg} / \mathrm{L}$ and Magnesium is $30 \mathrm{mg} / \mathrm{L}$. Daily requirement of Sodium and potassium in infant is $2-3 \mathrm{mEq} / \mathrm{kg}$ each $[27,28]$. Among the microminerals iron, zinc, copper and iodine are also necessary to maintain normal growth and maturation of the infant period and to boost the immune system though less in amount. Human milk contains iron in range of 0.3 to $0.6 \mathrm{mg} / \mathrm{L}$ [29]. American Academy of Pediatrics recommends iron needed in infant is $1 \mathrm{mg} / \mathrm{kg} /$ day which should be started after 4 months as they have enough iron stores till that age [30]. It has been seen that childhood anemia is influenced by low iron content in breast milk in addition to poor nutrition and maternal anemia. The severity of anemia increased with longer duration of breast feed [31]. During the start of breast feeding a more watery and thin milk precedes with low in volume, called foremilk and later on with more creamy thick milk called hind milk which high fat content.

\section{Foremilk Vs Hind milk [32,33] (Table 1):}

Table 1

\begin{tabular}{|c|c|c|c|}
\hline S. N & Characteristics & Fore Milk & Hind Milk \\
\hline 1. & Secreted & Start of feeding & $\begin{array}{l}\text { Later phase of } \\
\text { feeding }\end{array}$ \\
\hline 2. & Consistency & Thin and runny & Thick and creamy \\
\hline 3. & Volume & Less (183ml/day) & Less ( $318 \mathrm{ml} /$ day) \\
\hline 4. & Lipids content & $\begin{array}{l}\text { Less }(42 \% \text { of } \\
\text { calories) }\end{array}$ & $\begin{array}{c}\text { More }(55 \% \text { of } \\
\text { calories) }\end{array}$ \\
\hline 5. & Retinol & $\begin{array}{l}\text { Less (365micro- } \\
\mathrm{mo} / \mathrm{L})\end{array}$ & More (1.6 times) \\
\hline 6. & Tocopherol & Less $(0.55 \mathrm{mg} / \mathrm{L})$ & More (1.6 times) \\
\hline 7. & Protein & $\begin{array}{l}\text { More }(12 \% \text { of } \\
\text { calories })\end{array}$ & $\begin{array}{c}\text { Less ( } 9 \% \text { of calo- } \\
\text { ries) }\end{array}$ \\
\hline 8. & Energy & Less (575 Kcal/L) & More (1.3 times) \\
\hline
\end{tabular}


Difference between Term milk \& Preterm milk (Table 2)

Table 2

\begin{tabular}{|c|c|c|c|}
\hline S. N. & $\begin{array}{c}\text { Characteristics } \\
{[\mathbf{3 4 - 3 9 ]}}\end{array}$ & Term Milk & Preterm Milk \\
\hline 1 & Protein & $2 \mathrm{~g} / \mathrm{dl}$ & $2.7 \mathrm{~g} / \mathrm{dl}$ \\
\hline 2 & Fat content & Lower & Higher \\
\hline 3 & Lactose & Higher & Lower \\
\hline 4 & Phosphate & Higher & Lower \\
\hline 5 & Colostrum energy & $54 \mathrm{kcal} / \mathrm{dl}$ & $49 \mathrm{kcal} / \mathrm{dl}$ \\
\hline 6 & Mature milk & $63 \mathrm{kcal} / \mathrm{dl}$ & $73 \mathrm{kcal} / \mathrm{dl}$ \\
\hline 7 & $\begin{array}{c}\text { Phagocytes \& secre- } \\
\text { tory IgA }\end{array}$ & Lower & Higher \\
\hline 8 & EGF & $5-12 \mathrm{ng} / \mathrm{ml}$ & $\begin{array}{c}25-40 \mathrm{ng} / \mathrm{ml}(\text { colos- } \\
\text { trum) }\end{array}$ \\
\hline 9 & TGF Beta-2 & Lower & Higher \\
\hline 10 & IL-10 \& TNF-alpha & Higher & Lower \\
\hline 11 & IGF-1 & 2 to $19 \mathrm{ng} / \mathrm{ml}$ & $10 \mathrm{ng} / \mathrm{ml}$ (colostrum) \\
\hline 12 & $\begin{array}{c}\text { Hepatocyte Growth } \\
\text { Factor (HGF) }\end{array}$ & $1.8 \mathrm{ng} / \mathrm{ml}$ & $\begin{array}{c}2.2 \mathrm{ng} / \mathrm{ml} \text { (colos- } \\
\text { trum) }\end{array}$ \\
\hline
\end{tabular}

Insulin like Growth factor-1 (IGF-1) is responsible for the distal small and large intestines muscle growth. HGF is responsible and growth of intestinal epithelial cells [39]. The higher levels of immune factors in preterm milk can be a compensatory mechanism whereby in the mother during preterm labor, the breast shifts the immune content of the milk to provide more protection [40]. In contrast, Goldman et al. claims that increased immune factors in preterm milk could be due to increased maternal systemic inflammation leading to preterm delivery [41]. Nevertheless, most immune factors decrease over the first month regardless of gestational age, thus term and preterm milk become more similar over time as the chronological age of the baby increases.

Table 3
Factors for delayed initiation of breast feeding: It has been seen that delayed initiation of breastfeeding by more than one hour in first day of life and after 24- 48 hours increases the twice and thrice fold of infection related deaths in neonates [42].

There are number of reasons for delayed initiation of breastfeeding [43-48].

1. Prelacteal feeding

2. High risk pregnancies

3. Assisted deliveries and long hospital stays

4. Maternal illness

5. Preterm, ill or low birth weight babies

6. Hospital practices: mother-infant separation

7. Free samples of breast milk substitutes

From the day of delivery mother and family members should be counselled regarding exclusive breastfeeding. The Exclusive Breastfeeding (EBF) rate among $\leq 5$ months infants is higher in Nepal (66.3\%) compared to Bangladesh (46\%), India (47\%) and Pakistan (50\%) in South east Asia though WHO/ UNICEF recommended is above $90 \%$ [49]. Mothers are unable to receive adequate support to breastfeed for the recommended sixmonth duration due to several reasons among which the lack of environment and the trained health care staffs. All the public buses, train and airplanes too do not have adequate facilities to encourage breast feeding. Health centers and Hospitals at every level in a country should have the policy of Baby Friendly Hospital Initiative (BFHI). In 1991, BFHI was launched with 10 interventions in birthing facilities to protect, promote, and support successful breastfeeding (Table 3) [50]:

\begin{tabular}{|c|c|}
\hline \multicolumn{2}{|c|}{ Every facility providing maternity services and care for newborn infants should: } \\
\hline 1. & Have a written breastfeeding policy that is routinely communicated to all health care staff. \\
\hline 2. & Train all health care staffs in skills necessary to implement this policy. \\
\hline 3. & Inform all pregnant women about the benefits and management of breastfeeding. \\
\hline 4. & Help mothers initiate breastfeeding within a half-hour of birth. \\
\hline 5. & Show mothers how to breastfeed, and how to maintain lactation even if they should be separated from their infants. \\
\hline 6. & Give newborn infants no food or drink other than breastmilk unless medically indicated. \\
\hline 7. & Practise rooming in - allow mothers and infants to remain together - 24 hours a day. \\
\hline 8. & Gncourage breastfeeding on demand. \\
\hline 9. & Give no artificial teats or pacifiers (also called dummies or soothers) to breastfeeding infants. \\
\hline 10. & Foster the establishment of breastfeeding support groups and refer mothers to them on discharge from the hospital or clinic. \\
\hline
\end{tabular}

\section{Breast Milk Secretion}

Breasts, the mammary glands of human become functional only after postpartum during lactation. Breast has alveolar cells that secrete milk into the ductules and finally into the larger mammary ducts beneath the areola and nipple. The smooth muscles of the gland push the milk into the mouth of the newborn during suckling. The nipple becomes firm and flexible for the easy grasp in the newborn's mouth. Different hormonal influences affect it growth, milk secretion and ejection. Progesterone and estrogen during pregnancy stimulates the breast for the growth 
of the alveoli and ductules. Prolactin secreted from the anterior pituitary gland is responsible for the alveoli to secrete milk that has an autocrine control and continued synthesis depends upon the adequate amount of milk sucked or removed from the breast. Finally, oxytocin has role for 'milk let down reflex'. It helps to eject the milk by binding on myoepithelial cells causing the alveoli contract and expulsion of milk during feeding. It has been seen that milk ejection is a robust physiological response and milk ejection and milk ejection characteristics do not differ between the infant derived and 2 phase vacuum patterns as mothers may use electric pump [51]. Prolactin and Oxytocin both in mother increase the bond of mother and the newborn.

Factor that affect Breast Milk secretion: The major factor that negatively affects breast feeding is maternal anxiety. It increases maternal stress and decreases self-esteem. Maternal stress interferes with oxytocin release and self-esteem decreases mother-child interaction, finally both contributing in breast milk secretion and ejection [52].

\section{Positions of Successful Breastfeeding [53]:}

1. Cross Cradle Hold: This is the excellent position for women with caesarean section.

2. Clutch or Football Hold: It is beneficial for women with large breasts or inverted nipples

3. Side lying position: It is a c shaped hold for women with cesarean birth

After successful positioning, another important factor is successful latching. It should facilitate deep latch with wide open mouth of the newborn.

Signs of good latch are:

a) Well flanged lips of baby around the areola

b) Long deeper sucks with 1:1 ratio of suck and swallowing

c) Relaxed posture of baby with one or two drops of milk in mouth

d) Let down sensation of milk during ejection reflex

The baby can be removed gently from breast by inserting a clean finger in the corner of mouth. Newborns should be fed every 2-3 hourly and on demand with a frequency of 8-12 times in 24 hrs. Kangaroo Mother Care (KMC) has been effective on success of breastfeeding for empowering mother-child bond and it decreases the mean time to achieve full enteral feeding, increases exclusive breastfeeding and higher rate of weight gain in preterm low birth neonates [54]. Jelliffe DB [55] foresighted that breastfeeding would be relevant to "present-day interest in the consequences of infant nutrition on subsequent adult health" though Pediatrician Bo Vahlquist in 1981 made a remark that no mammalian species would have survived without the phase of breast feeding after pregnancy which comprise a complete reproductive cycle [56]. A target above $90 \%$ for any breastfeeding from 6-23 months has been already achieved by these five low socioeconomic countries viz. Nepal, Rwanda, Ethiopia, Burundi, and Guinea. In contrast the prevalence of breast feeding at 12 months is lower than $20 \%$ in most high-income countries like UK $(<1 \%)$, USA $(27 \%)$, Norway (35\%) and Sweden (16\%) [57]. As compared to low- and middle-income countries, high-income countries have shorter breastfeeding duration.

\section{Benefits of Breast Feeding [57-63]:}

Breast feeding is associated with strong protective effect in exclusively breastfed infants as well as mother. It affects the health of both the child and mother in short term and long term. Recently it was analyzed that infants who consumed breast milk for less than 6 months or have mothers who are obese at the start of pregnancy, are much more likely to have NAFLD at 17years of age [63].

\section{Benefits to the child (Table 4)}

\section{Table 4}

\begin{tabular}{|c|c|c|c|}
\hline \multicolumn{2}{|r|}{ Short Term Benefits } & \multicolumn{2}{|r|}{ Long Term Benefits } \\
\hline 1. & $\begin{array}{l}\text { Decrease in hospital } \\
\text { admissions }\end{array}$ & 1. & $\begin{array}{c}26 \% \text { reduction in obesity or } \\
\text { overweight }\end{array}$ \\
\hline 2. & $\begin{array}{l}\text { Protection against otitis } \\
\text { media }\end{array}$ & 2. & $\begin{array}{l}35 \% \text { reduction in type } 2 \\
\text { diabetes }\end{array}$ \\
\hline 3. & Adequate weight gain & 3. & Increase of 3.4 IQ points \\
\hline 4. & $\begin{array}{l}68 \% \text { reduction in maloc- } \\
\text { clusion }\end{array}$ & 4. & $\begin{array}{l}52 \% \text { risk reduction of Celiac } \\
\text { ds }\end{array}$ \\
\hline 5. & Decreases risk of NEC & 5. & $\begin{array}{l}15-20 \% \text { reduction in risk of } \\
\text { Leukemia }\end{array}$ \\
\hline 6. & Protection from ROP & 6. & $36 \%$ risk of SIDS \\
\hline 7. & Beneficial effects on heart & 7. & $\begin{array}{l}31 \% \text { risk reduction of child- } \\
\text { hood IBD }\end{array}$ \\
\hline 8. & $\begin{array}{l}\text { Prevent Bronchopulmona- } \\
\text { ry dysplasia }\end{array}$ & 8. & $9 \%$ reduction in asthma \\
\hline 9. & $\begin{array}{l}\text { Improves bond with } \\
\text { mother }\end{array}$ & 9. & Protection from NAFLD \\
\hline
\end{tabular}

IQ: Intelligence Quotient, NEC: Necrotizing Enterocolitis, ROP: Retinopathy of Prematurity, SIDS: Sudden Infant Death Syndrome, IBD: Inflammatory Bowel Disease, NAFLD: Non-Alcoholic Fatty Liver Disease

\section{Benefits to Mother (Table 5)}

Table 5

\begin{tabular}{|c|c|c|c|}
\hline \multicolumn{2}{|r|}{ Short Term Benefits } & \multicolumn{2}{|r|}{ Long Term Benefits } \\
\hline 1. & Lactational amenorrhea & 1. & $\begin{array}{c}\text { Decreases risk of type } 2 \\
\text { Diabetes }\end{array}$ \\
\hline 2. & Birth spacing & 2. & $\begin{array}{l}30 \% \text { reduction in ovarian } \\
\text { cancer }\end{array}$ \\
\hline 3. & $\begin{array}{l}\text { Increases Mother-Child } \\
\text { bond }\end{array}$ & 3. & $\begin{array}{l}\text { 4.3- } 7 \% \text { reduction in Breast } \\
\text { cancer }\end{array}$ \\
\hline 4. & $\begin{array}{l}\text { Decreases Maternal depres- } \\
\text { sion }\end{array}$ & 4. & $\begin{array}{l}\text { Happiness and harmony in } \\
\text { family }\end{array}$ \\
\hline 5. & Decreases weight retention & 5. & Reduces osteoporosis \\
\hline 6. & $\begin{array}{l}\text { Decreases Postpartum } \\
\text { bleeding }\end{array}$ & 6. & $\begin{array}{l}\text { Reduces cost and is econom- } \\
\text { ical }\end{array}$ \\
\hline
\end{tabular}




\section{Investigational Value:}

a) Breast milk Iodine concentration is more accurate than Urinary Iodine concentration for iodine status in exclusively breastfeeding women [64].

b) Dysregulated breastfeeding behavior involving vigorous sucking pattern without stopping by newborns in first weeks of life has been found to be recalled by half of the mothers with child diagnosed with Autism Spectrum Disorder (ASD) later [65].

\section{Contraindications to Breast Feeding [57]}

There are very few contraindications to breast feeding. Few of them are:

1. Metabolic disorder e.g. Galactosemia, phenylketonuria

2. HIV (except in countries where mortality increases due to infectious disease and malnutrition)

3. Untreated Brucellosis

4. Active Tuberculosis or Active Herpes Skin lesions in mother

5. Mothers acquiring varicella within 2-5 days of perinatal period

6. Mothers with active H1N1 infection

Literature has shown that breastfeeding can be continued safe in transplant recipient mothers in immunosuppressants (steroids, azathioprine and calcineurin inhibitors) though close follow up of infants is desirable [66]. Breast milk is so nice that glycosaminoglycans in milk prevents binding of HIV gp120 to the CD4 receptor thus reduces risk of transmission. Human milk lipids contribute to innate immunity and is against Giardia lamblia, $\mathrm{H}$ influenzae, group B streptococci, Staph epidermidis, respiratory syncytial virus, and herpes simplex virus type 1 [67]. Expressed breast milk can be considered in certain maternal conditions or where there is no concern of transmission of infectious organisms:

1. Mothers having varicella, H1N1 infection, tuberculosis

2. Mothers with smoking habit

3. Before drinking alcohol by mother

It is advisable to have low risk consumption of alcohol. Alcohol level peaks in about 30-60mins after ingestion and the infant will receive about $3 \%$ of maternal dose of alcohol when fed at peak concentration [68]. Ideally, breast feeding should be started within one hour of birth. Exclusive breast feeding should be for atleast for first six months of life and up to 2 years of age and beyond. Complementary feed with age-appropriate solid, semi-solid and soft foods have to be started at 6 months of age. Globally, breast feeding started within 1 hour is $44 \%$ [69].

Facilitators and Barriers of Exclusive Breast Feeding (EBF) [70]

\section{Facilitators of Exclusive Breast Feeding (EBF):}

a) EBF Is Good for Family Economy and Prevents Child Sickness

b) Breast feeding is only food for infants

c) EBF affects mother appearance

d) Breast milk is easily accessible to child \& no need to boil

e) It creates Happiness and Harmony in family

\section{Barriers of Exclusive Breast Feeding (EBF)}

a) Concept of Breast milk to be light

b) Breast feeding causes breast sag

c) Evil eye fear

d) Breast pain due to burping

e) Breast milk has bad odor

f) Circumstances that make Breast unclean

g) Breast feeding is tiring

\section{Unavailability of Human Breast milk}

Mothers breast milk may be unavailable in various circumstances. Only around $30 \%$ of extremely premature children can get breast milk. some of the reasons of unavailability are [71]:

1. Inadequate milk supply from mother due to maternal illness or stress

2. Delayed milk ejection reflex

3. Biological immaturity of mothers' mammary glands

4. Poor suckling of the newborn

5. Volume restrictions in newborn due to medical or cardiac illness

6. Limited nutrient supply with low minerals and vitamins

\section{Donor Human Milk \& Milk Bank}

Donor human milk is about donating a mother's surplus of milk to milk banks for high risk or low birth weight newborn babies. In 1909, Escherich opened the first human milk bank [72]. Milk Bank collects the breast milk from the safe donors, screens, pasteurizes, stores and finally may fortify with necessary ingredients and supplies to the hospitals for high risk newborns. Pasteurized human milk is considered safe though it can't fully compensate components of mother's own milk (MOM) for donor human milk (DHM). Pasteurization reduces the lactoferrin level in mother's milk by 88\% [73]. Combinedly the term 'Human milk feeding' is used for both MOM and DHM for very low birth weight infants. In contrast to MOM, DHM has not been able to reduce the sepsis or improve the neuro developmental outcome and studies have revealed slower growth in DHM fed vs MOM and formula 
fed very low birth weight infants. Still it is better than the bovinebased formulas due to latter causing gut epithelial cell toxicity, dysbiotic gut colonization and upregulation of inflammatory responses. This benefit has allowed DHM to be started before MOM is available to start enteral feedings and to reduce the risk of Necrotizing enterocolitis [74].

\section{Differences between MOM and DHM can be summarized as [74] (Table 6)}

Table 6

\begin{tabular}{|c|c|c|c|}
\hline S.N. & Characteristics & MOM & DHM \\
\hline 1. & Lactoferrin & High & Low \\
\hline 2. & Fortification & Absent & $\begin{array}{c}\text { Fortified with } \\
\text { bovine protein }\end{array}$ \\
\hline 3. & Antioxidants & High & Minimal or low \\
\hline 4. & IGF, TGF Beta & High & Low \\
\hline 5. & Sepsis prevention & High & Low \\
\hline 6. & Growth of infant & Fast & Slow \\
\hline 7. & Probiotic bacteria & Natural & Commercial \\
\hline 8. & Safety & High & $\begin{array}{c}\text { Can be question- } \\
\text { able }\end{array}$ \\
\hline
\end{tabular}

Rare species milk such as camel's milk which contains lot of protective proteins and immunoglobulins, minerals, vitamins, probiotic bacteria (lactic acid bacteria) and lack allergic proteins that are present in cow's milk, can be fortified with human milk or can serve as weaning substitute to children [75].

\section{Strategies to strengthen Exclusive Breast feeding}

The target of breast feeding to can be attained by

a. Encouraging the participation of young leaders in fostering this activity in every country is the initial step.

b. Ensuring the BFHI in every health centers and hospitals. c. Active participation of husband in encouraging breastfeeding

d. Extending Breast feeding breaks to atleast 6 months for breastfeeding mothers

e. Reinforcing and interrogation about breast feeding by birth attendants, obstetrician, pediatrician and community health workers.

f. Awareness dissemination about the short term and longterm benefits of breast feeding for the child

g. Encouraging mothers for maternal responsiveness towards the newborn

\section{Pyramid concept of Fostering Breast Feeding (Figure 1)}

Breastfeeding can be fostered in different levels from the individual, community and national level by creating awareness with evidence-based teaching, interactions and support. It starts from the initiation from the confidence of mother and father who must standby for encouraging the mother for breastfeeding practice. Breastfeeding is a neurodevelopmental activity. The optimized way of breastfeeding will coordinate the infant characteristics with the mother breastfeeding technique finally giving neurodevelopmental milestones to the child. This first step starts in home and should be supported by all family members especially the other elder people. At community level, obstetrician and pediatrician should be able to give their time to assess the right technique of breast feeding in mother. Health centers and hospitals should be equipped enough to advocate BFHI feelings. Finally, at national level there should be political and administrative will to encourage breastfeeding through policies and facilities cutting down all the barriers. The concept of Human Milk Bank can be initiated from the policy makers for the low birth weight children and those at high risk due to congenital anomalies and severe infections.

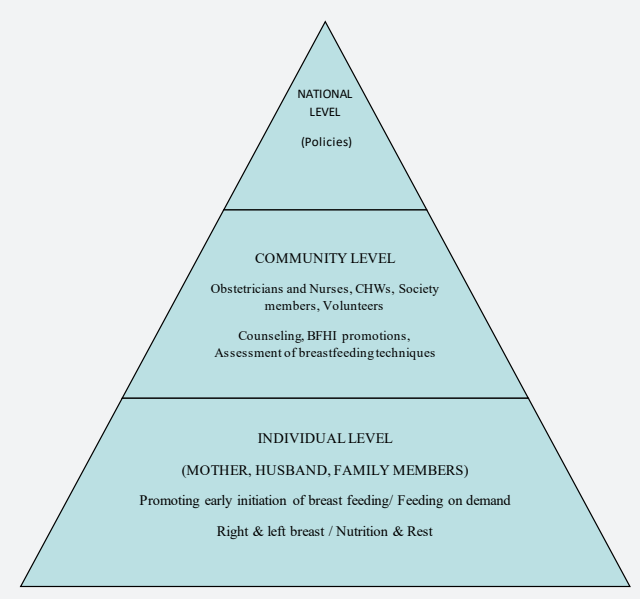

Figure 1

\section{Conclusion}

Thus, breastfeeding is important postnatal care in human life. Responsive breastfeeding has major impact on child health. It improves the health and development of the child and reduces the morbidity and mortality. 
Breastfeeding counselling is an effective public health measure that helps to understand the elements of exclusive breastfeeding and its impact on health of an individual and economic burden in national level. The cost of not breastfeeding may become high if we don't act today. The physician, nurses and community health workers at community level must ensure the mother for exclusive breastfeeding creating a strong bond between mother and child and her responsiveness to child. Moreover, the responsiveness should be contributed by father and other family members too. The foremost intervention is to spread the evidences at community level and fostering the attitude of society in breastfeeding culture. So, inculcating the culture breast feeding is needed not only to the rural mothers but also to the urban and city dwelling mothers, not only in the underdeveloped and poor countries but also in the developed world.

\section{References}

1. (1990) UNICEF. Innocenti Declaration on the Protection, Promotion and Support of Breastfeeding.

2. (2001) World Health Organization. The optimal duration of exclusive breastfeeding. Report of an expert consultation.

3. Victora CG, Aluísio JD, Barros AJD, França GVA, Horton S, et al. (2016) Breastfeeding in the $21^{\text {st }}$ century: epidemiology, mechanisms, and lifelong effect. Lancet 387(10017): 475-490.

4. Andreas NJ, Kampmann B, Mehring Le-Doare K (2015) Human breast milk: A review on its composition and bioactivity. Early Hum Dev 91(11): 629-635.

5. Ballard O, Morrow AL (2013) Human milk composition: nutrients and bioactive factors. Pediatr Clin North Am 60(1): 49-74.

6. Peterson JA, Patton S, Hamosh M (1998) Glycoproteins of the human milk fat globule in the protection of the breast-fed infant against infections. Biol Neonate 74(2): 143-162.

7. Nana Chea, Anteneh Asefa (2018) Prelacteal feeding and associated factors among newborns in rural Sidama, south Ethiopia: a community based cross-sectional survey. International Breastfeeding Journal 13(7).

8. Legesse M, Demena M, Mesfin F, Haile D (2014) Prelacteal feeding practices and associated factors among mothers of children aged less than 24 months in Raya Kobo district, North Eastern Ethiopia: a crosssectional study. Int Breastfeed J 9(1): 189.

9. Ogbo FA, Page A, Idoko J, Claudio F, Agho KE (2016) Diarrhoea and Suboptimal Feeding Practices in Nigeria: Evidence from the National Household Surveys. Paediatr Perinat Epidemiol 30(4): 346-355.

10. Nguyen PH, Keithly SC, Nguyen NT, Nguyen TT, Tran LM, et al. (2013) Prelacteal feeding practices in Vietnam: challenges and associated factors. BMC Public Health 13(932).

11. (2010) Ethiopian Health and Nutrition Research Institute (EHNRI). Nutritional Baseline Survey Report for the National Nutrition Program of Ethiopia.

12. Khanal V, Lee AH, Karkee R, Binns CW (2016) Prevalence and factors associated with prelacteal feeding in western Nepal. Women Birth 29(1): 12-17.

13. Goyle A, Jain P, Vyas S, Saraf H, Shekhawat, et al. (2004) Colostrum and prelacteal feeding practices followed by families of pavement and roadside squatter settlements. Ind J Prev Soc Med 35(1-2): 58-62.
14. Bandyopadhyay M (2009) Impact of ritual pollution on lactation and breastfeeding practices in rural West Bengal, India. Int Breastfeed J 4: 2.

15. Ojofeitimi EO, Olaogun AA, Osokoya AA, Owolabi SP (1999) Infant feeding practices in a deprived environment: a concern for early introduction of water and glucose D water to neonates. Nutr Health 13(1): 11-21.

16. Amele EA, Demissie BW, Desta KW, Woldemariam EB (2019) Prelacteal feeding practice and its associated factors among mothers of children age less than 24 months old in Southern Ethiopia. Ital J Pediatr 45(1): 15.

17. Khanal V, Adhikari M, Sauer K, Zhao Y (2013) Factors associated with the introduction of prelacteal feeds in Nepal: findings from the Nepal Demographic and Health Survey 2011. Int Breastfeed J 8(1): 9.

18. Lakati AS (2010) The effect of preclateal feeding on breast feeding in Nairobi, Kenya.

19. Butte NF, Goldblum RM, Fehl LM, Loftin K, Smith EO, et al. (1984) Daily ingestion of immunologic components in human milk during the first four months of life. Acta Paediatr Scand 73(3): 296-301.

20. Tregoat V, Montagne P, Bene MC, Faure G (2002) Changes in the mannan binding lectin (MBL) concentration in human milk during lactation. J Clin Lab Anal 16(6): 304-307.

21. Billeaud C, Guillet J, Sandler B (1990) Gastric emptying in infants with or without gastro-oesophageal reflux according to the type of milk. Eur J Clin Nutr 44(8): 577-583.

22. Berger HM, Scott PH, Kenward C, Scott P, Wharton BA (1979) Curd and whey proteins in the nutrition of low birthweight babies. Arch Dis Child 54(2): 98-104.

23. Schanler RJ, Goldblum RM, Garza C, Goldman AS (1986) Enhanced fecal excretion of selected immune factors in very low birth weight infants fed fortified human milk. Pediatr Res 20(8): 711-715.

24. Viña J, Vento M, García-Sala F, Puertes IR, Gascó E (1995) L-cysteine and glutathione metabolism are impaired in premature infants due to cystathionase deficiency. Am J Clin Nutr 61(15): 1067-1069.

25. Chesney RW, Helms RA, Christensen M, Budreau AM, Han X, (1998) The role of taurine in infant nutrition. Adv Exp Med Biol 442: 463-476.

26. Hamosh M (1987) Lipid metabolism in premature infants. Biol Neonate 52(1): 50-64.

27. Butte NF, Garza C, Johnson CA, Smith EO, Nichols BL (1984) Longitudinal changes in milk composition of mothers delivering preterm and term infants. Early Hum Dev 9(2): 153-162.

28. Roy RN, Chance GW, Radde IC, Hill DE, Willis DM, et al. (1976) Late hyponatremia in very low birthweight infants. (less than 1.3 kilograms). Pediatr Res 10(5): 526-531.

29. Siimes MA, Vuori E, Kuitunen P (1979) Breast milk iron--a declining concentration during the course of lactation. Acta Paediatr Scand 68(1): 29-31.

30. Robert D Baker, Frank R Greer (2010) Diagnosis and Prevention of Iron Deficiency and Iron-Deficiency Anemia in Infants and Young Children (0-3 Years of Age). Pediatrics November 126(5): 1040-1050.

31. Sean Buck, Kevin Rolnick, Amanda A Nwaba, Jens Eickhoff, Kelechi Mezu-Nnabue et al. (2019). Longer Breastfeeding Associated with Childhood Anemia in Rural South-Eastern Nigeria. International Journal of Pediatrics 2019.

32. Valentine CJ, Hurst NM, Schanler RJ (1994) Hindmilk improves weight gain in low-birth-weight infants fed human milk.J Pediatr Gastroenterol Nutr 18(4): 474-477. 
33. Bishara R, Dunn MS, Merko SE, Darling P (2008) Nutrient Composition of Hindmilk Produced by Mothers of Very Low Birth Weight Infants Born at Less Than 28 Weeks' Gestation. J Hum Lact 24(2): 159-167.

34. Gidrewicz DA, Fenton TR (2014) A systematic review and metaanalysis of the nutrient content of preterm and term breast milk. BMC Pediatrics 14: 216.

35. Jakaitis BM, Denning PW (2014) Human breast milk and the gastrointestinal innate immune system. Clin Perinatol 41(2): 423-435.

36. Castellote C, Casillas R, Ramirez-Santana C, Perez-Cano FJ, Castell $M$ et al (2011) Premature delivery influences the immunological composition of colostrum and transitional and mature human milk. J Nutr 141(6):1181-1187.

37. Maheshwari A, Kelly DR, Nicola T, Ambalavanan N, Jain SK et al (2011) TGF- $\beta 2$ suppresses macrophage cytokine production and mucosal inflammatory responses in the developing intestine. Gastroenterology 140(1): 242-253.

38. Lönnerdal B, Adkins Y (2000) Developmental changes in breast milk protein composition during lactation. In: Sanderson IR Walker WA, eds. Development of the gastrointestinal tract. Hamilton: B C Decker 227: 44.

39. Cummins AG, Thompson FM (2002) Effect of breast milk and weaning on epithelial growth of the small intestine in humans. Gut 51(5): 748754.

40. Nicole Theresa Cacho, Robert M Lawrence (2017) Innate immunity and Breast Milk. Front Immunol 8: 584.

41. Goldman AS, Garza C, Nichols BL, Goldblum RM (1982) Immunologic factors in human milk during the first year of lactation. J Pediatr 100(4): 563-567.

42. Mullany LC, Katz J, Li YM, Khatry SK, LeClerq SC, et al (2008). Breastfeeding patterns, time to initiation, and mortality risk among newborns in Southern Nepal. J Nutr 138(3): 599-603.

43. Kozhimannil KB, Jou J, Attanasio LB, Joarnt LK, McGovern P (2014) Medically complex pregnancies and early breastfeeding behaviors: a retrospective analysis. PLoS One 9(8): e104820.

44. Prior E, Santhakumaran S, Gale C, Philipps LH, Modi N, et al. (2012) Breastfeeding after cesarean delivery: a systematic review and metaanalysis of world literature. Am J Clin Nutr 95(5): 1113-1135.

45. Simmons D, Conroy C, Thompson CF (2005) In-hospital breast feeding rates among women with gestational diabetes and pregestational type 2 diabetes in South Auckland. Diabet Med 22(2): 177-181.

46. Adair LS, Popkin BM (1996) Low birth weight reduces the likelihood of breast-feeding among Filipino infants. J Nutr 126(1): 103-112.

47. Righard L, Alade MO (1990) Effect of delivery room routines on success of first breast-feed. Lancet 336(8723): 1105-1107.

48. Thurston A, Bolin JH, Chezem JC (2013) Infant formula samples: perinatal sources and breast-feeding outcomes at 1 month postpartum. J Perinat Neonatal Nurs 27: 353-358.

49. Khanal, V., Sauer, K. \& Zhao, Y (2013) Exclusive breastfeeding practices in relation to social and health determinants: a comparison of the 2006 and 2011 Nepal Demographic and Health Surveys. BMC Public Health 13: 958.

50. (2009) World Health Organization. Baby-Friendly Hospital Initiative. Revised, updated and expanded for integrated care.

51. Gardner (2019) Comparison of maternal milk ejection characteristics during pumping using infant-derived and 2-phase vacuum patterns. International Breastfeeding Journal (2019) 14: 47.
52. Zanardo V, Gasparetto S, Giustardi A, Suppiej A, Trevisanuto D, et al. (2009) Impact of anxiety in the puerperium on breast-feeding outcomes: role of parity. J Pediatr Gastroenterol Nutr 49(5): 631-634.

53. Lactation Review: Breastfeeding Basics https://lms.rn.com/getpdf. php/2012.pdf

54. Md Mahbubul Hoque, Nishat Jahan, Md Maksudur Rahman, Liton Chandra Saha, Rowsan Jahan Akhter, et al. (2017) Effectiveness of KMC on success of breastfeeding in preterm low birthweight neonate. Academic Journal of Pediatrics \& Neonatology, 3(4): 1-4.

55. Jelliffe DB, Jelliffe EFP (1978) Human milk in the modern world. BMJ 2(6151): 1573 .

56. Vahlquist B (1981) Introduction. Contemporary patterns of breastfeeding. Report of the WHO Collaborative Study on Breast-feeding.

57. Victora CG, Bahl R, Barros AJ, França GV, Horton S, et al. (2016) Breastfeeding in the $21^{\text {st }}$ century: epidemiology, mechanisms, and lifelong effect. Lancet 387(10017): 475-490.

58. (2012) Breastfeeding and the use of human milk. Pediatrics 129(3): 827-841.

59. Kalwart HJ, Specker BL (1995) Bone mineral loss during lactation and recovery after weaning. Obstet Gynecol 86(1): 26-32.

60. Blaauw R, Albertse EC, Beneke T, Lombard CJ, Laubscher R, et al. (1994) Risk factors for development of osteoporosis in a South African population. A prospective analysis. S Afr Med J 84(6): 328-332.

61. Spiegler J, Preuß M, Gebauer C, Bendiks M, Herting E, et al. (2016) Does Breastmilk Influence the Development of Bronchopulmonary Dysplasia? J Pediatr 169: 76-80.

62. Lewandowski AJ, Lamata P, Francis JM, Piechnik SK, Ferreira VM, et al. (2016) Breast Milk Consumption in Preterm Neonates and Cardiac Shape in Adulthood. Pediatrics 138(1).

63. Ayonrinde OT, Oddy WH, Adams LA, Mori TA, Beilin LJ et al. (2017) Infant nutrition and maternal obesity influence the risk of nonalcoholic fatty liver disease in adolescents. J Hepatol 67(3): 568-576.

64. Dold S, Zimmermann MB, Aboussad A, Cherkaoui M, Jia Q et al (2017). Breast Milk Iodine Concentration is a More Accurate Biomarker of Iodine Status than Urinary Iodine Concentration in Exclusively Breastfeeding Women. J Nutr 147(4): 528-537

65. Ruth Fitts Lucas, Ann Cutler (2015) Dysregulated Breastfeeding Behaviors in Children Later Diagnosed with Autism. J Perinat Educ 24(3): 171-80

66. Sameh M, Mohsen E k, Jon J K, Ahmed H, Ajay S (2017) Safety of Breastfeeding by Mothers on Immunosuppressive Medication for Renal Transplantation: Obsession, Myth and Truth. JOJ uro \& nephron 3(3).

67. Alison Stuebe (2009) The Risks of Not Breastfeeding for Mothers and Infants. Rev Obstet Gynecol 2(4): 222-231.

68. Paul Mullane, Mary T O’Mahony (2019) Alcohol consumption and breast feeding: A review of the evidence. Archives of Disease in Childhood 104(3): 1-428

69. (2019) UNICEF. Infant and young child feeding.

70. Melina Mgongo, Tamara H Hussein, Babill Stray-Pedersen, Siri Vangen, Sia E. Msuya, et al. (2019). Facilitators and Barriers to Breastfeeding and Exclusive Breastfeeding in Kilimanjaro Region, Tanzania: A Qualitative Study. International Journal of Pediatrics 2019.

71. Schanler RJ, Lau C, Hurst NM, Smith EO (2005) Randomized trial of donor human milk versus preterm formula as substitutes for mothers' own milk in the feeding of extremely premature infants. Pediatrics 116(2): 400-406. 
72. Jones, Frances (2003) History of North American Donor Milk Banking: One Hundred Years of Progress. J Hum Lact 19(3): 313-318.

73. Underwood M, Scoble, J (2015) Human milk and the premature infant: Focus on the use of pasteurized donor human milk in the NICU. Diet and nutrition in critical care 795-806.

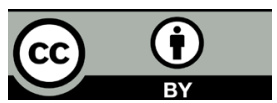

This work is licensed under Creative Commons Attribution 4.0 Licens DOI:_10.19080/AJPN.2019.08.555794
74. Paula P, Meier et al (2017). Donor Human Milk Update: Evidence, Mechanisms and Priorities for Research and Practice. J Pediatr 180: 15-21.

75. Anjali Sharma, Meeta Lavania, Banwari Lal (2019) Rare Species Milk as a New Source for Potential LABs. Nutri Food Sci Int J 9(3): 555762.

\section{Your next submission with Juniper Publishers} will reach you the below assets

- Quality Editorial service

- Swift Peer Review

- Reprints availability

- E-prints Service

- Manuscript Podcast for convenient understanding

- Global attainment for your research

- Manuscript accessibility in different formats

( Pdf, E-pub, Full Text, Audio)

- Unceasing customer service

Track the below URL for one-step submission

https://juniperpublishers.com/online-submission.php 